$\begin{gathered}\text { Науковий вісник НлтУ України } \\ \text { Scientific Bulletin of UNFU } \\ \text { https://nv.nltu.edu.ua }\end{gathered}$
$\begin{array}{r}\text { https://doi.org/10.36930/40310307 } \\ \text { Article received 13.05.2021 p. } \\ \text { Article accepted 29.04.2021 p. } \\ \text { UDC 630*1:581.524.33(477.42) }\end{array}$
ISSN 2519-2477 (online)
$\begin{aligned} & \text { Correspondence author } \\ & \text { O. L. Kratiuk }\end{aligned}$
deneshi_ks@ukr.net

О. Л. Кратюк', О. О. Орлов ${ }^{2}$

${ }^{1}$ Поліський національний університет, м. Житомир, Україна ${ }^{2}$ ДУ "Інститут геохімії навколишнього середовищза НАН Украӥни", м. Київ, Украйна

\title{
ЗМІНА ГРУНТОВИХ ПАРАМЕТРІВ У СВІЖОМУ ДУБОВО-СОСНОВОМУ СУБОРІ ПІД ВПЛИВОМ НАПІВВІЛЬНОГО УТРИМАННЯ МИСЛИВСЬКИХ ТВАРИН В УМОВАХ ЦЕНТРАЛЬНОГО ПОЛІССЯ
}

\begin{abstract}
Оцінювання впливу напіввільного утримання мисливських тварин на компоненти лісових біогеоценозів є актуальним завданням для запобігання та унеможливлення їх деградації. Дослідження здійснено на території двох об'єктів напіввільного утримання мисливських тварин, користувачами яких є ДП "Баранівське ЛМГ" (Явненське лісництво) та ТОВ "Клуб "КСК" (Поташнянське л-во ДП "Радомишльське ЛМГ") у межах Центрального Полісся. Ступінь впливу напіввільного утримання мисливських тварин визначено в умовах свіжого дубово-соснового субору $\left(\mathrm{B}_{2}\right.$-дС) на підставі повних геоботанічних описів методом порівняння бальної оцінки грунтових параметрів: вологості грунту (Hd), мінливості зволоження грунту (Fh), кислотності грунту $(\mathrm{Rc})$, кількості солей $(\mathrm{Sl})$, вмісту мінерального азоту $(\mathrm{Nt})$, вмісту кальцію та магнію у грунті (Са), аерованості грунту (Ае). Встановлено, що середні бали вологості грунту (контроль $11,93^{ \pm 0,12}$; вольєр $11,89^{ \pm 0,11}$ ) та аерованості грунту (контроль $6,38^{ \pm 0,08}$; вольєр $6,46^{ \pm 0,08}$ ) у вольєрах та на контрольних ділянках не мають достовірної різниці. Інші грунтові параметри мають тенденцію до збільшення у межах вольєрів порівняно з контрольними ділянками. Так, перемінність зволоження грунту на контрольних ділянках характеризувалася середнім балом $5,36^{ \pm 0,11}$, збільшуючись у вольєрах до $5,94^{ \pm 0,14}$ бала $\left(F_{\text {факm. }}=10,58>F_{0,95}=4,30\right)$, кислотність грунту становила $5,80^{ \pm 0,12}$ бала на контрольній ділянці, збільшуючись у вольєрах до $6,49^{ \pm 0,11}$ бала $\left(F_{\text {факт. }}=17,36>F_{0,95}=4,30\right)$. Збільшення виявлено як для загальної кількості солей у грунті, так $\mathrm{i}$ для кальцію та магнію, а також для мінерального азоту. Загальний вміст солей оцінено у $5,33^{ \pm 0,01}$ бала на контролі, тоді у вольєрі він становив $5,78^{ \pm 0,12}$ бала $\left(F_{\text {факm }}=9,14>F_{0.95}=4,30\right)$. кількість кальцію та магнію у грунтах контролю та у вольєрі характеризу-

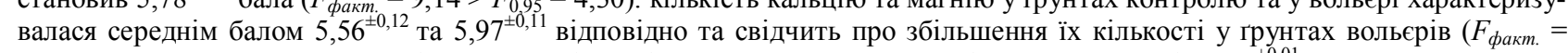
$\left.6,29>F_{0,95}=4,30\right)$. Виявлено збільшення вмісту мінерального азоту у грунті в середньому від $4,16^{ \pm 0,01}$ бала на контрольних ділянках до $4,74^{ \pm 0,11}$ бала на ділянках вольєрного утримання тварин $\left(F_{\text {факт. }}=27,33>F_{0,95}=4,30\right)$. Збільшення у вольєрах показників кислотності грунту, вмісту кальцію, магнію та мінерального азоту зумовлене, вірогідно, привнесенням до грунту солей натрію, калію та азотистих речовин з сечею та екскрементами ратичних тварин.
\end{abstract}

Ключові слова: фітоіндикація; лісові екосистеми; тип лісу; вольєр; ратичні тварини.

\section{Вступ}

Вихід із довготривалої кризи мисливського господарства України можливий завдяки розвитку вольєрного господарства $[17,19,35]$. Попри позитивні аспекти ведення вольєрного господарства для користувачів мисливських угідь, процес напіввільного утримання ратичних тварин створює певний негативний тиск на лісові екосистеми. Згаданий вплив $є$ багатогранним. Визначальними чинниками впливу мисливських тварин на лісові біогеоценози є: прямі, зокрема поїдання певних кормових видів або їх частин, витоптування (знищення, зміна) рослинного покриву, особливо поблизу та безпосередньо на підгодівельних майданчиках; опосередковані - зміна фізичних та хімічних властивостей грунтів у процесі життедіяльності тварин [18, 22, 23, 29], а його величина залежить від площі вольєра, щільності, видового складу та вікової структури популяції, умов утримання, заходів та обсягів підгодівлі. За умови напіввільного утримання мисливських тварин зазначені чинники можуть кардинально впливати на видовий склад нижніх ярусів лісової рослинності, що відображається у трансформації нижніх ярусів лісових біогеоценозів. Так, наприклад, ущільнення грунтів $\epsilon$ спільним екологічним параметром для зоогенних та рекреагенних змін, для останніх продемонстровано чіткий тренд рекреагенної деградації нижніх ярусів лісової рослинності, а також виражена динаміка грунтових параметрів [1].

Тому, для зниження дії зазначених процесів на лісові екосистеми, потрібно проводити багатофакторний їх аналіз з розробленням моделі раціонального і невис-

\section{Інформація про авторів:}

Кратюк Олександр Леонідович, канд. біол. наук, доцент, завідувач кафедри експлуатації лісових ресурсів. Email: deneshi_ks@ukr.net; https://orcid.org/0000-0002-2661-8074

Орлов Олександр Олександрович, канд. біол. наук, ст. наук. співробітник, відділ екогеології та термодинаміки сфер. Email: orlov.botany@gmail.com; https://orcid.org/0000-0003-2923-5324

Цитування за ДСту: Кратюк О. Л., Орлов О. О. Зміна ґрунтових параметрів у свіжому дубово-сосновому суборі під впливом напіввільного утримання мисливських тварин в умовах Центрального Полісся. Науковий вісник НлТУ України. 2021, т. 31, № 3. C. 49-56.

Citation APA: Kratiuk, O. L., \& Orlov, O. O. (2021). Change of soil parameters in fresh oak-coniferous forest conditions under the influence of semi-free maintenance of game animals in Central Polissya. Scientific Bulletin of UNFU, 31(3), 49-56. https://doi.org/10.36930/40310307 
нажливого використання не лише мисливських, а й лісових ресурсів.

Об'єкт дослідження - процес зміни грунтових параметрів у свіжому дубово-сосновому суборі $\left(\mathrm{B}_{2}-д \mathrm{C}\right)$ під впливом вольєрного утримання мисливських тварин в умовах Центрального Полісся.

Предмет дослідження - закономірності зміни грунтових параметрів у свіжому дубово-сосновому суборі $\left(\mathrm{B}_{2}\right.$-дС) під впливом вольєрного утримання мисливських тварин.

Мета роботи - аналіз закономірностей зміни грунтових параметрів у свіжому дубово-сосновому суборі $\left(\mathrm{B}_{2}-\right.$-д) під впливом вольєрного утримання мисливських тварин

Для досягнення зазначеної мети визначено такі основні завдання дослідження:

1) за допомогою кількісної фітоіндикації розрахувати зміни параметрів грунту у свіжому дубово-сосновому суборі $\left(\mathrm{B}_{2}-\mathrm{CC}\right)$ під впливом напіввільного утримання мисливських тварин;

2) оцінити глибину трансформації нижніх ярусів лісової рослинності за умов вольєрного утримання ратичних тварин.

Наукова новизна отриманих результатів дослідження - вперше для вольєрів Центрального Полісся України виявлено особливості впливу напіввільного утримання ратичних тварин на грунтові параметри у свіжому дубово-сосновому суборі ( $\left.\mathrm{B}_{2}-д \mathrm{C}\right)$.

Практична значущість результатів дослідження результати наших досліджень спонукають до розроблення та впровадження методів ранньої діагностики зоогенної дигресії рослинного покриву в умовах інтенсивного ведення мисливського господарства загалом та у вольєрах зокрема. Вивчення зміни параметрів грунту методами фітоіндикації дасть змогу розробити методологічну основу довготривалого моніторингу стану лісових екосистем за умов напіввільного утримання мисливських тварин. Це стане основою для унормування щільності популяцій ратичних тварин у вольєрах, а також інтенсивності біотехнічних заходів з урахуванням типологічної структури лісових насаджень.

Аналіз останніх досліджень та публікацій. Особливістю грунтового покриву суборів Полісся $є$ критично низькі запаси гумусу і рухомих форм азоту у кореневмісному шарі, а також напружені режими щодо кальцію та фосфору, передусім, через низький їх фоновий вміст і високу потребу рослин у зазначених біофільних елементах [32]. Специфіка формування гумусного стану і поживного режиму грунтів у різних лісорослинних умовах Полісся України висвітлено у роботах $[2,16,22]$. Ратичні тварини, як невід'ємний компонент лісових біогеоценозів, $є$ потужним біогеоценотичним чинником у процесах грунтотворення [4, 27, 28], впливаючи на формування вмісту гумусу та біофільних елементів $[9,10]$. Особливо інтенсивно це відбувається у вольєрах, де процеси життєдіяльності (живлення, переміщення), обмеженість життєвого простору разом з високою щільністю популяцій ратичних тварин чинять значний тиск на поверхню грунту, зумовлюючи трансформацію живого надгрунтового покриву. Основними наслідками такого впливу $є$ значне ущільнення грунту, зміна вмісту біогенних елементів, трансформація біологічної активності [13, 37]. Все це призводить до істотних змін видового складу та ценотичної будови лісових біогеоценозів. Серед ярусів лісової рослинності трав'яно-чагарничковий ярус виступає як синтетичний, дуже чутливий індикатор умов місцезростань та екологічних змін у них, а отже, найпридатніший для фітоіндикації [7, 8, 31, 34]. Однак варто зазначити, що дослідники наголошували на тому, що для фітоіндикації доцільно використовувати не окремі види рослин або їх групи, а видовий склад фітоценозу загалом $[6,26,30,36]$, адже зазвичай видовий склад лісових фітоценозів утворений більш-менш евритопними видами, зі широкими географічними ареалами та екологічними амплітудами відносно екологічних, зокрема і грунтових параметрів. Але у видовому складі практично кожного рослинного угруповання трапляються стенотопні види - 3 вузькою екологічною амплітудою відносно певного чинника середовища. Саме такі види слугують найкращими індикаторами певних екологічних, зокрема і грунтових, умов, ці стенотопні види у поєднанні з рештою видів рослин фітоценозу є дуже чутливими індикаторами умов середовища. В Україні для кожного з видів судинних рослин розроблено кількісну (бальну) оцінку екологічних, зокрема і грунтових параметрів $[5,8]$.

Отже, незважаючи на усвідомлення потужного впливу напіввільного утримання мисливських тварин на лісові біогеоценози, у процесах моніторингу не приділяли достатньої уваги вивченню екологічного стану грунтового покриву у розрізі типологічної структури лісових насаджень [3]. Водночас було продемонстровано придатність фітоіндикації для оцінювання динаміки грунтових параметрів під час відновлення лісових екосистем після суцільних рубок головного користування у соснових лісах Західного Полісся [33], дубових лісах Правобережного Полісся [14, 15], рекреагенних змінах широколистяних лісів Закарпатської низовини [1].

Тому оцінювання впливу вольєрного утримання ратичних тварин на грунтові параметри є актуальним завданням для мінімізації впливу на грунти та унеможливлення їх деградації.

Матеріали та методи дослідження. Дослідження проведено у 2019 р. у свіжому дубово-сосновому суборі $\left(\mathrm{B}_{2}\right.$-дC) на підставі 24 повних геоботанічних описів у межах 4 біогеоценозів на території двох вольєрів, користувачами яких є ДП "Баранівське ЛМГ" та ТОВ "Клуб "КСК". Закладання пробних площ виконано загальноприйнятими методами геоботаніки $[12,25]$, в усіх випадках вони мали форму квадрата $100 \times 100$ м. У кожному біогеоценозі описано по три непошкоджені (контрольні) ділянки та три ділянки, пошкоджені тваринами у межах вольєра.

Флористичний склад усіх ярусів лісових фітоценозів вивчали за А. А. Корчагіним [20], надалі для фітоіндикаційних досліджень головну увагу приділено трав'яночагарничковому ярусу, як найбільш флористично багатому та динамічному. Для кожного виду судинних рослин і мохів визначали проективне покриття.

Фітоіндикацію параметрів грунту на контрольних, не пошкоджених тваринами ділянках, та на ділянках у межах вольєрів виконували у межах кожного з 4 біогеоценозів за методологією Я. П. Дідуха, П. Г. Плюти [8]. Кількісні значення балів головних грунтових параметрів для видів судинних рослин отримано з монографії Я. П. Дідуха [5]. Екологічні характеристики видів мохоподібних оцінювали за шкалами, розробленими Р. Дюллом [11]. За допомогою програми "Sphyt" розраховували бали головних параметрів грунту для кожного геобо- 
танічного опису: $\mathrm{Hd}$ - вологості грунту, $\mathrm{Fh}$ - перемінності зволоження, Rc - кислотності, $\mathrm{Sl}$ - сольового режиму (загальної кількості солей у грунті), Са - кількості карбонатів кальцію і магнію у грунті, $\mathrm{Nt}$ - кількості азоту, Ае - аерованості грунту. На їх основі для кожного біогеоценозу стандартними методами варіаційної статистики [24] розраховували статистичні показники для параметрів грунту - для контрольних ділянок та ділянок у межах вольєрів з вираженими зоогенними змінами рослинного покриву. Для статистичної оцінки значущості різниці значень досліджених параметрів грунту у згаданих двох групах пробних площ у кожному біогеоценозі та за типом лісу загалом використано однофакторний дисперсійний аналіз.

\section{Результати дослідження та їх обговорення}

Вольєр у ДП "Баранівське ЛМГ" створено згідно 3 рішенням технічної ради Баранівського лісгоспзагу від 16.03.1985 р. на площі 56,2 га на території Явненського лісництва для розведення оленя плямистого (Cervus nippon Temminck, 1838), з подальшим відловом та розсе- ленням у мисливські угіддя України. У вольєрі упродовж усього існування постійно утримують від 30 до 50 особин оленя плямистого. Вольєр ТОВ "Клуб "КСК", на території Поташнянського лісництва ДП "Радомишльське ЛМГ", створений у період 1997-1998 pp. на площі 61,0 га для розведення кабана дикого (Sus scrofa Linnaeus, 1758). Чисельність виду упродовж існування вольєра змінювалася від 15 до 50 особин основного поголів'я. На момент проведення досліджень у вольєрі утримували 12 особин кабана дикого різного віку.

Для вольєрів ТОВ "Клуб "КСК" та ДП "Баранівське ЛМГ" характерне переважання суборових типів лісу. У цих вольєрах домінують свіжі дубово-соснові субори (B ${ }_{2}$-дС). Їх площа становить 35,1 га, або 62,5% (ДП "Баранівське ЛМГ") та 39,3 га, або 64,4% (ТОВ "Клуб "КСК") [21].

На підставі фітоіндикаційних досліджень отримано розрахункові дані головних грунтових параметрів, які узагальнено у таблиці.

Таблиця. Середні значення балів грунтових параметрів у свіжому дубово-сосновому суборі (B-дС) на території вольєрів та за їх межами (контроль)

\begin{tabular}{|c|c|c|c|c|c|c|c|}
\hline \multirow{2}{*}{ Середнє значення з похибкою } & \multicolumn{7}{|c|}{ Параметри грунту } \\
\hline & $\mathrm{Hd}$ & Fh & $\mathrm{Rc}$ & Sl & $\mathrm{Ca}$ & $\mathrm{Nt}$ & $\mathrm{Ae}$ \\
\hline \multicolumn{8}{|c|}{ ДП "Баранівське ЛМГ" (Явненське л-во) } \\
\hline \multicolumn{8}{|c|}{$\begin{array}{l}\text { 1. Контроль: сосновий ліс орляково-зеленомоховий (Pinus sylvestris }+ \text { Pteridium aquilinum }+ \\
\text { Dicranum polysetum + Pleurozium schreberi) }\end{array}$} \\
\hline$M$ & 11,26 & 5,95 & 5,84 & 5,75 & 5,83 & 4,16 & 5,98 \\
\hline$m$ & 0,05 & 0,13 & 0,11 & 0,09 & 0,08 & 0,06 & 0,07 \\
\hline \multicolumn{8}{|c|}{ У вольєрі: сосновий ліс рідкотравний (Pinetum sparsaeherbosum) } \\
\hline$M$ & 11,36 & 6,40 & 7,08 & 6,30 & 6,49 & 5,14 & 6,42 \\
\hline$m$ & 0,15 & 0,10 & 0,03 & 0,06 & 0,04 & 0,14 & 0,14 \\
\hline \multicolumn{8}{|c|}{$\begin{array}{c}\text { 2. Контроль: сосновий ліс орляково-чорницево-зеленомоховий (Pinus sylvestris }+ \text { Pteridium aquilinum }+ \\
\text { Vaccinium myrtillus }+ \text { Dicranum polysetum }+ \text { Pleurozium schreberi) }\end{array}$} \\
\hline$M$ & 12,13 & 5,18 & 5,29 & 5,37 & 5,08 & 4,17 & 6,61 \\
\hline$m$ & 0,01 & 0,05 & 0,04 & 0,13 & 0,06 & 0,01 & 0,02 \\
\hline \multicolumn{8}{|c|}{ У вольєрі: сосновий ліс рідкотравний (Pinetum sparsaeherbosum) } \\
\hline$M$ & 12,02 & 5,85 & 6,18 & 5,91 & 5,70 & 4,97 & 6,77 \\
\hline$m$ & 0,08 & 0,17 & 0,07 & 0,06 & 0,01 & 0,13 & 0,09 \\
\hline \multicolumn{8}{|c|}{ 3. Контроль: сосновий ліс зеленомоховий (Pinetum hylocomiosum) } \\
\hline$M$ & 12,23 & 5,29 & 6,39 & 5,23 & 6,05 & 4,14 & 6,39 \\
\hline$m$ & 0,03 & 0,03 & 0,03 & 0,02 & 0,03 & 0,02 & 0,01 \\
\hline \multicolumn{8}{|c|}{ У вольєрі: сосновий ліс рідкотравний (Pinetum sparsaeherbosum) } \\
\hline$M$ & 12,28 & 5,40 & 6,54 & 5,30 & 6,08 & 4,32 & 6,43 \\
\hline$m$ & 0,07 & 0,02 & 0,01 & 0,01 & 0,02 & 0,05 & 0,05 \\
\hline \multicolumn{8}{|c|}{ ТОВ "Клуб "КСК" (Поташнянське л-во ДП "Радомишльське ЛМГ") } \\
\hline \multicolumn{8}{|c|}{ 4. Контроль: сосновий ліс орляково-чорницевий (Pinus sylvestris + Pteridium aquilinum +Vaccinium myrtillus) } \\
\hline$M$ & 12,11 & 5,01 & 5,66 & 4,96 & 5,27 & 4,17 & 6,56 \\
\hline$m$ & 0,01 & 0,04 & 0,06 & 0,02 & 0,06 & 0,003 & 0,02 \\
\hline \multicolumn{8}{|c|}{ У вольєрі: сосновий ліс орляково-наземнокуничниковий (Pinus sylvestris +Pteridium aquilinum +Calamagrostis epigeios) } \\
\hline$M$ & 11,90 & 6,12 & 6,18 & 5,60 & 5,59 & 4,51 & 6,22 \\
\hline$m$ & 0,05 & 0,36 & 0,11 & 0,11 & 0,07 & 0,06 & 0,18 \\
\hline
\end{tabular}

Проаналізуємо зміни значень екологічних параметрів місцезростань на підставі бальної оцінки у типі лісу свіжий дубово-сосновий субір $\left(\mathrm{B}_{2}\right.$-дС) у 4 лісових екосистемах.

В екосистемі на контролі - у сосновому лісі орляково-зеленомоховому (Pinus sylvestris+Pteridium aquilinum + Dicranum polysetum+Pleurozium schreberi). Дані таблиці свідчать, що вологість грунту $(\mathrm{Hd})$ в ній становила $11,26^{ \pm 0,05}$ бала, що відповідало мезофітним умовам свіжих лісолучних екотопів 3 повним промочуванням кореневмісного шару грунту атмосферними опадами i талими водами. Середні значення перемінності зволо- ження (Fh) характеризувалися балом $5,95^{ \pm 0,13}$, що характерно для гемігідроконтрастофобних умов лісолучних екотопів з помірно нерівномірним зволоженням кореневмісного шару грунту за його повного промочування. Кислотність грунту (Rc) у цій екосистемі дорівнювала в середньому $5,84^{ \pm 0,11}$ бала, що свідчило про ацидофільні умови зі значеннями $\mathrm{pH}$ у межах 4,5-5,5. Кількість солей у грунті (Sl) характеризувалася середнім балом $5,75^{ \pm 0,09}$, що є властивим для мезотрофних умов лісів - 3 небагатими на солі грунтами (у межах 95-150 мг/л), де наявні карбонати (іони $\mathrm{HCO}_{3}^{-}$) та відсутні сульфати і хлориди $\left(\mathrm{SO}_{4}{ }^{2-}, \mathrm{Cl}^{-}\right)$. Вміст кальцію та магнію у грунті 
(Са) характеризувався середніми значеннями $5,83^{ \pm 0,08}$ бала, що віддзеркалювало гемікарбонатофобні умови, в яких вміст $\mathrm{CaO}$ та $\mathrm{MgO}$ у грунті дорівнював близько $0,5 \%$, що загалом характерно для бореальних хвойних лісів Українського Полісся. Кількість азоту у грунті (Nt) досліджуваного біогеоценозу характеризувалася середнім балом $4,16^{ \pm 0,06}$, що свідчить про субанітрофільні, бідні на мінеральний азот грунти із вмістом цього елемента живлення у діапазоні значень 0,050,2 \% або 5-20 мг на 100 г грунту, що загалом є властивим дерново-слабопідзолистим піщаним і легкосупіщаним грунтам. Аерованість грунту (Ае) дорівнювала $5,98^{ \pm 0,07}$ бала або 80-55 \%, що відповідало субаерофільним умовам, значно аерованим грунтам піщаного і легкосупіщаного гранулометричного складу.

Внаслідок вольєрного використання проаналізованої вище екосистеми утворився сосновий ліс рідкотравний (Pinetum sparsaeherbosum), в якому грунтові параметри відрізнялися від таких на непорушених вихідних ділянках. Зокрема, середній бал вологості грунту, порівняно 3 вихідним біогеоценозом, дещо збільшився - до $11,36^{ \pm 0,15}$ бала, різниця не була істотною на $95 \%$-му довірчому рівні $\left(F_{\text {факт. }}<<F_{0,95}\right)$. Перемінність зволоження також збільшилася - від 5,95 $5^{ \pm 0,13}$ до $6,40^{ \pm 0,13}$ бала, наведена різниця також не була істотною на 95 \%-му довірчому рівні $\left(F_{\text {факт. }}<F_{0,95}\right)$. Середній бал кислотності грунту на ділянках вольєрного використання значно збільшився порівняно 3 контролем - до 7,08 $8^{ \pm 0,03}$ бала, що свідчить про субацидофільні умови у грунті, з діапазоном величини $\mathrm{pH}$ у межах 5,5-6,5. Різниця середніх значень цього параметра порівняно 3 контролем, була істотною на $95 \%$-му довірчому рівні $\left(F_{\text {факт. }}=113,15>>\right.$ $\left.F_{0,95}=7,71 ; p=0,0004\right)$. Загальна кількість солей на ділянках вольєрного використання істотно збільшилася порівняно з контролем - до $6,30^{ \pm 0,06}$ бала $\left(F_{\text {факт. }}=26,11\right.$ $\left.>>F_{0,95}=7,71 ; p=0,007\right)$. Кількість кальцію та магнію у грунтах ділянок вольєрів також істотно збільшилася від $5,83^{ \pm 0,08}$ до $6,49^{ \pm 0,04}$ бала $\left(F_{\text {факт. }}=49,50>F_{0,95}=\right.$ $7,71 ; p=0,002)$. Розрахунки також засвідчили істотне збільшення кількості азоту у грунті - до $5,14^{ \pm 0,14}$ бала $\left(F_{\text {ракт. }}=41,51>F_{0,95}=7,71 ; p=0,003\right)$, що свідчить про трансформацію субанітрофільних умов у гемінітрофільні умови у грунті, характерні для відносно бідних на мінеральний азот грунтів 3 діапазоном вмісту цього елемента живлення 0,2-0,3 \%. Аерованість грунту також істотно збільшилася порівняно 3 контролем, середній бал збільшився до $6,42^{ \pm 0,14}$ бала $\left(F_{\text {факm. }}=8,25>F_{0,95}=\right.$ $7,71 ; p=0,045)$. Збільшення аерованості грунту можна пояснити впливом рийної діяльності ратичних тварин.

На контролі, у сосновому лісі орляково-чорницевозеленомоховому (Pinus sylvestris+Pteridium aquilinum + Vaccinium myrtillus + Dicranum polysetum + Pleurozium schreberi) вологість грунту становила $12,13^{ \pm 0,01}$ бала, що відповідало мезофітним умовам свіжих лісолучних екотопів 3 повним промочуванням кореневмісного шару грунту атмосферними опадами і талими водами. Перемінність зволоження характеризувалася середнім балом $5,18^{ \pm 0,05}$, що $є$ властивим для гемігідроконтрастофобних умов лісолучних екотопів 3 помірно нерівномірним зволоженням кореневмісного шару грунту за його повного промочування. Середній бал кислотності грунту на контролі дорівнював 5,29 $9^{ \pm 0,04}$ бала, що вказує на ацидофільні умови 3 діапазоном рН від 4,5 до 5,5. Сольовий режим (кількість солей у грунті) характеризу- вався середнім балом $5,37^{ \pm 0,13}$, що відповідало мезотрофним умовам з небагатими на солі дерново-слабопідзолистими грунтами, із вмістом солей у межах 95150 мг/л, наявності $\mathrm{HCO}^{3-}$, відсутності $\mathrm{SO}_{4}{ }^{2-}$ та $\mathrm{Cl}^{-}$. Вміст кальцію та магнію у грунтах оцінено 5,08 ${ }^{ \pm 0,06}$ бала, що характеризувало умови в них як гемікарбонатофобні, з вмістом $\mathrm{CaO}$ та $\mathrm{MgO}$ близько 0,5 \%. Кількість азоту у грунті була дещо вища порівняно 3 попередньою екосистемою, із середнім балом $4,17^{ \pm 0,01}$, що $€$ властивим для субанітрофільних, дуже бідних на мінеральний азот дерново-слабопідзолистих грунтів із вмістом азоту 0,05-0,2 \% або 5-20 мг на 100 г грунту. Аерованість грунту характеризувалася середнім балом $6,61^{ \pm 0,02}$, що відповідало геміаерофобним умовам (аерованість дорівнювала 50-35 \%), властивим помірно аерованим піщаним або легкосупіщаним грунтам 3 повним промочуванням профілю або тимчасовим надмірним зволоженням.

У похідному біогеоценозі, де внаслідок вольєрного використання утворився сосновий ліс рідкотравний (Pinetum sparsaeherbosum), грунтові параметри зазнали значних змін. Зокрема, вологість грунту дещо зменшилася - до $12,02^{ \pm 0,08}$ бала, при цьому різниця 3 контролем у цього параметра була неістотною на 5 \%-му рівні значущості $\left(F_{\text {факт. }}<F_{0,95}\right)$. Перемінність зволоження істотно збільшилася - від 5,18 $8^{ \pm 0,05}$ бала на контролі до $5,85^{ \pm 0,17}$ бала у вольєрі $\left(F_{\text {факт. }}=13,55>F_{0,95}=7,71\right.$; $p=0,02)$, залишившись, однак, у межах гемігідроконтрастофобних умов. Середній бал кислотності грунту значно збільшився - від 5,29 $\pm 0,04$ бала на контролі до $6,18^{ \pm 0,07}$ бала у вольєрі $\left(F_{\text {qакm. }}=111,74>>F_{0,95}=7,71\right.$; $p=0,0005)$, втім, залишившись у межах ацидофільних умов 3 величиною $\mathrm{pH}$ у межах 4,5-5,5. Кількість солей у грунті у вольєрі була істотно вищою порівняно 3 контролем і дорівнювала 5,91 $1^{ \pm 0,06}$ бала, різниця з контролем була істотною на $95 \%$-му довірчому рівні $\left(F_{\text {факт. }}=\right.$ $\left.15,49>F_{0,95}=7,71 ; p=0,02\right)$ і зумовлювалася, головним чином, привнесенням у грунт солей з екскрементами тварин у вольєрному утриманні. Кількість кальцію та магнію у грунтах вольєрів була істотно вищою порівняно 3 контролем. Середній бал цього параметра збільшився від $5,08^{ \pm 0,06}$ бала на контролі до $5,70^{ \pm 0,01}$ бала у вольєрі, наведена різниця середніх була істотною на $95 \%$-му довірчому рівні $\left(F_{\text {факт. }}=111,50>F_{0,95}=7,71\right.$; $p=0,0004)$ і відповідала гемікарбонатофобним умовам із вмістом $\mathrm{CaO}$ та $\mathrm{MgO}$ у грунтах близько $0,5 \%$. Середній бал кількості азоту у грунті досліджуваної екосистеми у вольєрах збільшився до $4,97^{ \pm 0,13}$ бала, що було значно вище, ніж на контролі $\left(F_{\text {факт. }}=36,11>>F_{0,95}=\right.$ $7,71 ; p=0,004)$. Це свідчить про трансформацію дуже бідних на мінеральний азот субанітрофільних умов у грунті у дещо багатші гемінітрофільні умови, характерні для відносно бідних на мінеральний азот грунтів із вмістом цього елемента живлення у діапазоні 0,2-0,3 \%. Середній бал аерованості грунту неістотно збільшився у вольєрах порівняно 3 контролем - до $6,77^{ \pm 0,09}$ бала, згадана різниця не була істотною на 5 \%-му рівні значущості $\left(F_{\text {факт. }}<F_{0,95}\right)$.

На контролі у свіжому дубово-сосновому суборі (B ${ }_{2}$ дС), в екосистемі соснового лісу зеленомохового (Pinetum hylocomiosum), загалом, величини грунтових параметрів були близькими до таких на контролі у двох проаналізованих вище екосистемах. Зокрема, середній бал вологості грунту становив $12,23^{ \pm 0,03}$ бала, що відпо- 
відало мезофітним умовам свіжих лісолучних екотопів 3 повним промочуванням кореневмісного шару грунту атмосферними опадами і талими водами. Перемінність зволоження характеризувалася середнім балом $5,29^{ \pm 0,03}$ бала, що характерно для гемігідроконтрастофобних умов лісолучних екотопів 3 помірно нерівномірним зволоженням упродовж року. Середній бал кислотності грунту дорівнював на контролі $6,39^{ \pm 0,03}$ бала, що характеризувало його грунтові умови як ацидофільні, 3 діапазоном рН від 4,5 до 5,5. Кількість розчинних солей у грунті характеризувалася середнім балом $5,23^{ \pm 0,02}$, що свідчило про мезотрофні умови, 3 небагатими на солі грунтами (вміст солей - 95-150 мг/л), за наявності $\mathrm{HCO}_{3}^{-}$, відсутності $\mathrm{SO}_{4}{ }^{2-}$ та $\mathrm{Cl}^{-}$. Середній бал кількості кальцію та магнію дорівнював $6,05^{ \pm 0,03}$ бала, що відповідало гемікарбонатофобним умовам у грунті (вміст $\mathrm{CaO}$ та $\mathrm{MgO}$ близько 0,5 \%). Кількість мінерального азоту у грунті характеризувалася середнім балом $4,14^{ \pm 0,02}$, що свідчило про субанітрофільні умови, властиві дуже бідним на мінеральний азот дерново-слабопідзолистим грунтам, вміст азоту в них коливався у межах 0,05-0,2 \% або 5-20 мг на 100 г грунту. Середній бал аерованості грунту дорівнював $6,39^{ \pm 0,01}$, що відповідало субаерофільним умовам, властивим значно аерованим грунтам піщаного та легкосупіщаного гранулометричного складу, в яких аерованість знаходилася у діапазоні 80-55\%.

Внаслідок зоогенної сукцесії проаналізованого вище біогеоценозу у вольєрі сформувався сосновий ліс рідкотравний (Pinetum sparsaeherbosum), грунтові параметри якого зазнали значних змін порівняно з вихідним біогеоценозом на контролі (див. таблицю). Зокрема, вологість грунту лише дещо збільшилася - до $12,28^{ \pm 0,07}$ бала, різниця 3 контролем була неістотною на 95 \%-му довірчому рівні $\left(F_{\text {факт. }}<F_{0,95}\right)$. Перемінність зволоження істотно збільшилася - від $5,29^{ \pm 0,03}$ до $5,40^{ \pm 0,02}$ бала $\left(F_{\text {paкm. }}=9,14>F_{0,95}=7,71 ; p=0,004\right)$. Подібна тенденція спостерігалася й у середнього балу кислотності грунту, котрий збільшився, порівняно 3 контролем, до $6,54^{ \pm 0,01}$ бала, а відповідно, кислотність грунту зменшилася. Різниця середніх значень на контролі й у вольєрі була істотною на $95 \%$-му довірчому рівні $\left(F_{\text {факт. }}=\right.$ $\left.27,66>F_{0,95}=7,71 ; p=0,006\right)$, втім, залишившись у межах ацидофільних умов 3 величиною $\mathrm{pH}$ у межах 4,55,5. Кількість розчинних солей у грунті у вольєрі характеризувалася середнім балом $5,30^{ \pm 0,01}$ бала, що було значно вищим порівняно з контролем $\left(F_{\text {факт. }}=18,38>\right.$ $\left.F_{0,95}=7,71 ; p=0,01\right)$ і пояснювалося привнесенням солей до грунту з екскрементами тварин. Кількість солей кальцію і магнію у грунті збільшилася до $6,08^{ \pm 0,02}$ бала, що відповідало мезотрофним умовам з небагатими на солі грунтами (95-150 мг/л). Це підвищення не було статистично значущим на $5 \%$-му рівні значущості $\left(F_{\text {факт. }}<F_{0,95}\right)$. Середній бал мінерального азоту у грунтах істотно збільшився - від $4,14^{ \pm 0,02}$ бала на контролі до $4,32^{ \pm 0,05}$ бала у вольєрах $\left(F_{\text {факт. }}=12,87>F_{0,95}=7,71\right.$; $p=0,02)$, що зумовлено привнесенням азотистих речовин до грунту переважно 3 сечею тварин. Аерованість грунту у вольєрах дещо зросла - до $6,43^{ \pm 0,05}$ бала, вірогідно, внаслідок помірної рийної діяльності ратичних тварин. Різниця цього показника на контролі та у вольєрах у досліджуваній екосистемі не була істотною на $95 \%$-му довірчому рівні.
У тому самому типі лісу $\left(\mathrm{B}_{2}-д \mathrm{C}\right)$ на контролі у сосновому лісі орляково-чорницевому (Pinus sylvestris +Pteridium aquilinum+Vaccinium myrtillus) грунтові параметри були досить близькими до наведених вище для контролю в інших екосистемах цього типу лісу (див. таблицю). Так, вологість грунту характеризувалася середнім балом $12,11^{ \pm 0,01}$, що відповідало мезофітним умовам свіжих лісолучних екотопів 3 повним промочуванням кореневмісного шару грунту атмосферними опадами і талими водами. Середній бал перемінності зволоження дорівнював $5,01^{ \pm 0,04}$, що характерно для гемігідроконтрастофобних умов 3 помірно нерівномірним зволоженням грунту. Кислотність грунту характеризувалася середнім балом $5,66^{ \pm 0,06}$, що свідчило про ацидофільні умови у грунті 3 діапазоном значень $\mathrm{pH}$ від 4,5 до 5,5, що загалом властиво дерново-слабопідзолистим піщаним грунтам соснових лісів у свіжих суборах $\left(\mathrm{B}_{2}\right)$. Середній бал кількості розчинних солей у грунті становив $4,96^{ \pm 0,02}$, що свідчить про мезотрофні умови, 3 небагатими на солі грунтами (вміст солей - 95150 мг/л), за наявні $\mathrm{HCO}_{3}{ }^{-}$, відсутні $\mathrm{SO}_{4}{ }^{2-}$ та $\mathrm{Cl}^{-}$. Середній бал кількості кальцію та магнію дорівнював $5,27^{ \pm 0,06}$, що характеризувало грунтові умови на контролі як гемікарбонатофобні, із вмістом $\mathrm{CaO}$ та $\mathrm{MgO}$ у грунті близько 0,5 \%. Кількість азоту у грунті контролю характеризувалася середнім балом $4,17^{ \pm 0,003}$, що є властивим для субанітрофільних умов 3 дуже бідними на мінеральний азот дерново-слабопідзолистими піщаними грунтами, 3 вмістом азоту у межах 0,05-0,2 \% або 520 мг на 100 г грунту. Аерованість грунтів характеризувалася середнім значенням $6,56^{ \pm 0,02}$ бала, що відповідало субаерофільним умовам значно аерованих екотопів, iз грунтами піщаного або легкосупіщаного гранулометричного складу (аерованість становить 80-55 \%).

Унаслідок вольєрного використання проаналізованого вище біогеоценозу грунтові параметри зазнали значних змін. Зокрема, вологість грунту від $12,11^{ \pm 0,01}$ бала на контролі зменшилася у вольєрі до $11,90^{ \pm 0,05}$ бала, різниця згаданих середніх значень була істотною на $95 \%$-му довірчому рівні $\left(F_{\text {факт. }}=18,37>F_{0,95}=7,71\right.$; $p=0,01)$. Перемінність зволоження грунту у вольєрі також істотно збільшилася, середній бал дорівнював $6,12^{ \pm 0,36}\left(F_{\text {ракт. }}=9,39>F_{0,95}=7,71 ; p=0,04\right)$, що, вірогідно, зумовлено локальним ущільненням грунту тваринами. Середній бал кислотності грунту збільшився від $5,66^{ \pm 0,06}$ на контролі до $6,18^{ \pm 0,11}$ у вольєрі, відповідно, кислотність грунту зменшилася, причому це зменшення було істотним на $95 \%$-му довірчому рівні $\left(F_{\text {факm. }}=\right.$ $\left.18,48>F_{0,95}=7,71 ; p=0,01\right)$. Вміст розчинних солей у грунті вольєр істотно збільшилася, середній бал цього показника виріс до $5,60^{ \pm 0,11}\left(F_{\text {факт. }}=31,23>F_{0,95}=7,71\right.$; $p=0,005)$, залишившись, однак, у межах мезотрофних умов 3 небагатими на солі грунтами. Це збільшення відбулося внаслідок привнесення до грунту солей з екскрементами ратичних тварин. Подібна тенденція спостерігалася також у вмісту кальцію та магнію у грунті вольєрів, середній бал цього показника збільшився до $5,59^{ \pm 0,07}$, це збільшення було істотним на $5 \%$-му рівні значущості $\left(F_{\text {факт. }}=11,00>F_{0,95}=7,71 ; p=0,03\right)$, однак не вийшло за межі гемікарбонатофобних умов, характерних для контролю. Кількість мінерального азоту у грунтах вольєрів значно збільшилася, відповідно, середній бал цього показника $34,17^{ \pm 0,07}$ на контролі збільшився до $4,51^{ \pm 0,06}$ у вольєрах. Згадане збільшення було 
істотним на $95 \%$-му довірчому рівні $\left(F_{\text {факт. }}=28,50>\right.$ $\left.F_{0,95}=7,71 ; p=0,006\right)$, що зумовлено привнесенням до грунту азотистих речовин із сечею тварин. Середній бал аерованості грунту зменшився у вольєрі до $6,22^{ \pm 0,18}$, зменшення не було істотним на $5 \%$-му рівні значущості $\left(F_{\text {факт. }}<F_{0,95}\right)$.

Узагальнюючи отримані дані для кожного 34 біогеоценозів у межах типу лісу свіжий дубово-сосновий субір $\left(\mathrm{B}_{2}-д \mathrm{C}\right)$, ми виконали розрахунки середніх значень усіх досліджених параметрів у межах цього типу лісу, та оцінили статистичну значущість середніх значень досліджених параметрів на контролі та ділянках вольєрного утримання ратичних тварин (рисунок).

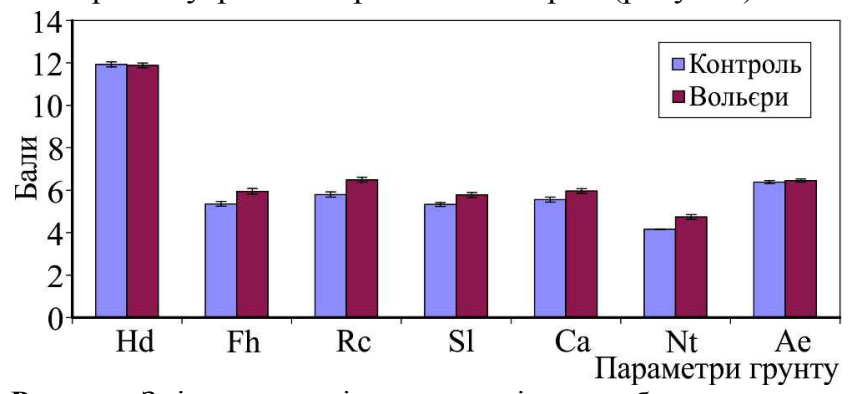

Рисунок. Зміна параметрів грунту у свіжому дубово-сосновому суборі ( $\mathrm{B}_{2}$-дС) у вольєрах Центрального Полісся та за їх межами (контроль)

Згідно з даними рисунка встановлено, що у свіжому дубово-сосновому суборі $\left(\mathrm{B}_{2}-д \mathrm{C}\right)$ середній бал вологості грунту (Hd) на ділянках контролю дорівнював $11,93^{ \pm 0,12}$, а у вольєрах $-11,89^{ \pm 0,11}$, різниця наведених середніх даних була неістотною на 95 \%-му довірчому рівні $\left(F_{\text {факт. }}=0,07<<F_{0,95}=4,30\right)$.

3 рисунка випливає, що перемінність зволоження грунту на контрольних ділянках у типі лісу $\mathrm{B}_{2}$-дС характеризувалася середнім балом $5,36^{ \pm 0,11}$, збільшуючись у вольєрах до $5,94^{ \pm 0,14}$ бала, це збільшення було істотним на $95 \%$-му довірчому рівні $\left(F_{\text {факт. }}=10,58>F_{0,95}=\right.$ $4,30 ; p=0,004)$. Середній бал кислотності грунту на контролі у досліджуваному типі лісу становив $5,80^{ \pm 0,12}$ бала, збільшуючись у вольєрах до $6,49^{ \pm 0,11}$ бала, що свідчить про істотне зменшення кислотності грунту $\left(F_{\text {факт. }}=17,36>F_{0,95}=4,30 ; p=0,0004\right)$, зумовлене, вірогідно, привнесенням до грунту солей натрію та калію 3 сечею ратичних тварин. Кількість солей у грунті у типі лісу $\mathrm{B}_{2}$-дC характеризувалася середнім балом $5,33^{ \pm 0,01}$, тоді як у вольєрах відбулося значне збільшення цього показника до $5,78^{ \pm 0,12}-$ переважно внаслідок привнесення до грунту солей з екскрементами тварин. Наведена різниця середніх значень була істотною на $5 \%$-му рівні значущості $\left(F_{\text {факт. }}=9,14>F_{0,95}=4,30\right.$; $p=0,006)$.

Кількість кальцію та магнію у грунтах контролю і вольєрів у типі лісу $\mathrm{B}_{2}$-дС характеризувалася середнім

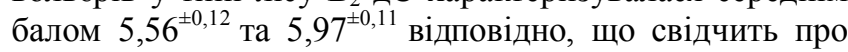
істотне збільшення кількості цих макроелементів у грунтах вольєрів порівняно з контролем $\left(F_{\text {факт. }}=6,29>\right.$ $\left.F_{0,95}=4,30 ; p=0,02\right)$. Щодо вмісту мінерального азоту у грунті, у типі лісу $\mathrm{B}_{2}$-дС відбулося значне збільшення цього показника - у середньому від $4,16^{ \pm 0,01}$ бала на контрольних ділянках до $4,74^{ \pm 0,11}$ бала на ділянках вольєрного утримання тварин. Статистичний аналіз даних дав змогу зробити висновок про значущість різниці наведених середніх значень $\left(F_{\text {факт. }}=27,33>>F_{0,95}=\right.$ 4,$\left.30 ; p=3,0 \times 10^{-5}\right)$, що свідчить про значне привнесення азотистих речовин до грунту із сечею тварин. На контрольних ділянках і ділянках вольєрного утримання тварин середні значення балів аерованості грунту дорівнювали відповідно $6,38^{ \pm 0,08}$ та $6,46^{ \pm 0,08}$ бала, які не відрізнялися істотно на $5 \%$-му рівні значущості $\left(F_{\text {факт. }}=\right.$ $\left.0,46<<F_{0,95}=4,30\right)$.

Обговорення результатів дослідження. Отримані результати визначення зміни параметрів грунту шляхом фітоіндикації мають певні особливості порівняно $з$ результатами аналізу фізико-хімічних властивостей грунтів. Встановлено, що інтенсивне тривале використання лісових насаджень для напіввільного утримання мисливських тварин впливає на фізико-хімічні показники грунтів. Так, у вольєрі ДП "Баранівське ЛМГ" зафіксовано значне підкислення грунту, $\mathrm{i}$ за рівнем $\mathrm{pH}_{\text {сол. }}$ реакція грунту з кислої стала сильнокислою, а також зафіксовано незначне зниження вмісту гідролізованого азоту і рухомого калію відносно контролю, що не виходило за межі похибки досліду. Загалом на підгодівельних майданчиках 4 вольєрів Західного і Центрального Полісся, які були створені у борах і суборах, грунти характеризуються дуже низьким вмістом гідролізованого азоту $\left(76,70^{ \pm 36,72}\right.$ мг/кг грунту) [23]. Варто зазначити, що відбір грунтових зразків на території вольєрів проводили винятково у межах підгодівельних майданчиків, тобто у місцях найінтенсивнішого впливу мисливських тварин на грунти. У літературі є відомості про відсутність чіткої закономірності у змінах вмісту рухомих форм фосфору у грунтах різних лісорослинних умов під впливом рийної діяльності кабана дикого [3].

Загалом тенденція до збільшення вмісту біофільних елементів за умови тривалої експлуатації вольєрів, на нашу думку, пов'язана безпосередньо 3 прямою дією продуктів життєдіяльності (екскрементів, сечі) диких тварин, особливо, поблизу та безпосередньо на підгодівельних майданчиках. Результати наших досліджень дали змогу дійти висновку, що чим інтенсивнішою була підгодівля ратичних тварин у вольєрі, тим більшої зміни зазнали досліджені агрохімічні грунтові параметри, зокрема вміст розчинних солей, вміст кальцію та магнію та азоту не лише на підгодівельних майданчиках та поблизу них, але й по всій території вольєра. Також дослідження продемонстрували, що чим більшим був вміст розчинних солей та кальцію та магнію у грунтах, тим меншою була їх кислотність, що можна пояснити закономірностями дисоціації солей, представлених у грунтах переважно карбонатами, де кальцій і магній сильні лужні елементи, а вугільна кислота - слабка. Отже, продукти дисоціації карбонатів мають лужну реакцію, що, відповідно, зменшує кислотність грунтів.

Прямий вплив екскрецій ратичних тварин, за літературними даними [10], призводить до збільшення пористості та вологості грунтів, а також через активізацію мікробіологічної активності у грунтах сприяє процесам гумусоутворення. Пористість грунтів є визначальним параметром їх аерованості, яка, за нашими даними, у вольєрах дещо збільшилася порівняно 3 контролем, проте це збільшення не було статистично достовірним. Порушене питання є важливим і потребує подальшого вивчення.

\section{Висновки}

У типі лісу $\mathrm{B}_{2}$-дС зміни вологості грунтів у вольєрах не були статистично значущими порівняно 3 контроль- 
ними ділянками. Перемінність зволоження грунтів у вольєрах статистично істотно зросла порівняно 3 контрольними ділянками, що зумовлено ущільненням грунтів у вольєрах під впливом ратичних тварин.

У суборах, де переважають дерново-підзолисті грунти різного ступеня опідзоленості, у вольєрах відбувається статистично значуще зменшення кислотності грунтів, вірогідно, внаслідок привнесення до грунту лужних елементів - натрію та калію - 3 екскрементами тварин.

Результати фітоіндикації засвідчили статистично значуще збільшення кількості кальцію та магнію у грунтах вольєрів порівняно 3 контрольними ділянками, що також зумовлено переважно привнесенням солей до грунту з екскрементами тварин.

Кількість мінерального азоту у грунтах вольєрів статистично істотно збільшилася порівняно 3 контролем. Це збільшення зумовлене привнесенням азотистих речовин до грунту із сечею ратичних тварин.

На контрольних ділянках і ділянках вольєрного утримання тварин аерованість грунтів не відрізнялася істотно на $5 \%$-му рівні значущості.

Здійснені дослідження можуть стати основою для подальшого вивчення впливу напіввільного утримання мисливських тварин на грунтові параметри з обов'язковою диференціацією за типами лісорослинних умов, що дасть змогу розробити механізми збереження, охорони та відтворення лісових екосистем в умовах вольєрного утримання мисливських тварин.

\section{References}

1. Blinkova, O. I. (2014). Synfitoindykatsiia rekreahennykh zmin ekolohichnykh umov zapovidnoho urochyshcha "Borzhava" (Zakarpatska nyzovynna oblast). Visnyk ONU. Seriia: Biolohiia. Vol. 19, 2(35), 21-33. [In Ukrainian].

2. Bondar, I. P. (2000). Kilkisni ta yakisni pokaznyky opadu v riznykh typakh umov mistsezrostannia lisostaniv Kyivskoho Polissia ta yikh vplyv na grunt. Naukovyi visnyk natsionalnoho ahrarnoho universytetu, 27, 94-103. [In Ukrainian].

3. Bondarenko, V. D., Bilyi, V. V., \& Khodzinskyi, V. P. (2007). Zmina fizyko-khimichnykh vlastyvostei gruntu pid vplyvom ryiuchoi diialnosti svyni dykoi. Problemy Zakhidnoho Polissia. Naukovyi visnyk Nadsluchanskoho instytutu, 1, 117-121. [In Ukrainian].

4. Bulakhov, V. L., Pakhomov, A. S., \& Pilipko, E. N. (2015). Vliianie roiushhei deiatelnosti kabana (Sus scrofa Linnaeus, 1758) na komponenty razlichnykh biogeotcenozov. Izvestiia Irkutskogo gosudarstvennogo universiteta. Seriia: Biologiia. Ekologiia. Vol. 13, 16-26. [In Russian].

5. Diduch, Ya. P. (2011). The ecological scales for the species of Ukrainian flora and their use in synphytoindication. Kyiv: Phytosociocentre, $176 \mathrm{p}$.

6. Didukh, Ia. P., Emshanov, D. G., \& Shkolnikov, Iu. A. (1997). Ispolzovanie fitoindikatcionnykh otcenok pri izuchenii struktury lesnykh ekosistem. Ekologiia, 5, 353-360. [In Russian].

7. Didukh, Ya. P. (2012). Osnovy bioindykatsii. Kyiv: Naukova dumka, 344 p. [In Ukrainian]

8. Didukh, Ya. P., \& Pliuta, P. H. (1994). Fitoindykatsiia ekolohichnykh faktoriv. Kyiv: Naukova dumka, 280 p. [In Ukrainian].

9. Domnich, A. (2014). Zoogenic influence on the amount of soil nitrogen in Azov-Syvash national nature park. Visnyk Lvivskoho universytetu. Seriia biolohichna, 67, 108-117. [In Ukrainian].

10. Domnich, A. V., \& Viazovska, A. H. (2013). Zmina pokaznykiv gruntu pid vplyvom vysokoi shchilnosti kopytnykh v raioni pivnichnoho uzberezhzhia Azovskoho moria. Naukovyi visnyk Uzhhorodskoho universytetu. Seriia: Biolohiia, 35, 113-122. [In Ukrainian].
11. Düll, R. (1984-1985). Distribution of the European and Macaronesian Mosses (Bryophytina). Bryologische Beitraege, 4(5), $1-232$.

12. Iunatov, A. A., Lavrenko, E. M., \& Korchagin, A. A. (Eds.). (1964). Zalozhenie ekologicheskikh profilei i probnykh ploshhadei. Polevaia geobotanika. Vol. III. Moscow - Leningrad: Nauka, Leningradskoe otd., 9-35. [In Russian].

13. Iurkova, N. E., Iurkov, A. M., \& Smagin, A. V. (2008). Otcenka funktcionalnogo sostoianiia pochv Moskovskogo zooparka po mikrobiologicheskim pokazateliam. Vestnik Moskovskogo universiteta. Seriia 17. Pochvovedenie, 3, 39-44. Retrieved from: https://cyberleninka.ru/article/n/otsenka-funktsionalnogo-sostoyaniya-pochv-moskovskogo-zooparka-po-mikrobiologicheskim-pokazatelyam. [In Russian].

14. Ivaniuk, I. D. (2021). Dubovi derevostany Pravoberezhnoho Polissia Ukrainy ta yikh lisivnycho-ekolohichnyi potentsial: Abstract of Doctoral Dissertation for Agricultural Sciences (06.03.03 - Silvics and forestry). Kyiv, 48 p. [In Ukrainian].

15. Ivaniuk, I. D., \& Ivaniuk, T. M. (2018). Dynamika ekolohichnykh parametriv gruntiv u protsesi vidnovlennia roslynnosti dubovykh lisiv Polissia. Forestry, Forest, Paper and Woodworking Industry, 44, 35-42. [In Ukrainian].

16. Ivaniuk, T. M. (2013). Fizyko-khimichni parametry gruntiv svizhykh suhrudiv Polissia Ukrainy. Scientific Bulletin of UNFU, 23(4). pp. 40-44. [In Ukrainian].

17. Kaminetskyi, V. K., Babich, O. H., \& Smahol, V. M. (2011). Ekolohichni ta hospodarski aspekty napivvilnoho rozvedennia dykykh kopytnykh (na prykladi spetsializovanykh pidpryiemstv Derzhavnoho upravlinnia spravamy Prezydenta Ukrainy): monohrafiia. Myronivka: ZAT "Myronivska drukarnia", 154 p. [In Ukrainian].

18. Kazeev, K. Sh., Zhadobin, A. V., Lesina, A. L., Aleksandrov, A. A., Bakaeva, Iu. S., Kravtcova, N. E., \& Kolesnikov, S. I. (2018). Ekologicheskoe sostoianie pochv volerov s zhivotnymi i ptitcami Rostovskogo zooparka. AgroEkoInfo, 3. Retrieved from: http://agroecoinfo.narod.ru/journal/STATYI/2018/3/st_358.doc. [In Russian].

19. Khoietskyi, P. B., Novak, A. A., \& Pokhaliuk, O. M. (2015). Svitovyi dosvid vedennia voliernoho myslyvskoho hospodarstva. Scientific Bulletin of UNFU, 25(3), 32-37. Retrieved from: https://nv.nltu.edu.ua/index.php/journal/article/view/1119. [In Ukrainian].

20. Korchagin, A. A., \& Lavrenko E. M. (Eds.). (1964). Vidovoi (floristicheskii) sostav rastitelnykh soobshhestv i metody ego izucheniia. Polevaia geobotanika. Vol. III, 39-5. Moscow-Leningrad: Nauka, Leningradskoe otd. 9. [In Russian].

21. Kratiuk, O. L. (2019). Typolohichna struktura lisovykh nasadzhen ta biotopichna kharakterystyka volieriv Tsentralnoho Polissia. Scientific Bulletin of UNFU,29(2), 62-64. https://doi.org/10.15421/40290212

22. Kratiuk, O. L., Kravchuk, M. M., \& Dovbysh, L. L. (2019). Vmist humusu u gruntakh volohykh suhrudiv na terytorii volieriv Zakhidnoho i Tsentralnoho Polissia. Scientific Bulletin of UNFU, 29(9), 27-31. https://doi.org/10.36930/40290904

23. Kratiuk, O. L., Kravchuk, M. M., \& Dovbysh, L. L. (2020). Bioheotsenotychna rol voliernoho utrymannia ratychnykh ARTIODACTYLA na khimichni vlastyvosti gruntiv u borakh i suborakh $\mathrm{v}$ umovakh Zakhidnoho i Tsentralnoho Polissia. Ecological sciences, 4(31), 143-149. https://doi.org/10.32846/23069716/2020.eco.4-31.23

24. Lakin, G. F. (1973). Biometriia. Moscow: Vysshaia shkola, 348 p. [In Russian].

25. Lavrenko, E. M., \& Korchagin, A. A. (Eds.). (1959). Osnovnye zakonomernosti rastitelnykh soobshhestv i puti ikh izucheniia. Polevaia geobotanika. Moscow-Leningrad: Nauka, Leningradskoe otd., 13-70. [In Russian].

26. Matusiak, M. V. (2015). Fitoindykatsiia ekolohichnykh faktoriv osnovnykh typiv lisovykh ekosystem v umovakh Podillia. Scientific Bulletin of UNFU, 25(6), 165-170. Retrieved from: https://nv.nltu.edu.ua/index.php/journal/article/view/931. [In Ukrainian]. 
27. Pakhomov, A. E. (1998). Biogeotcenoticheskaia rol mlekopitaiushhikh $\mathrm{v}$ pochvoobrazovatelnykh protcessakh stepnykh lesov Ukrainy. Kniga 1. Mekhanicheskii tip vozdeistviia. Dnepropetrovsk, 232 p. [In Russian].

28. Pakhomov, A. E. (1998). Biogeotcenoticheskaia rol mlekopitaiushhikh $\mathrm{v}$ pochvoobrazovatelnykh protcessakh stepnykh lesov Ukrainy. Kniga 2. Troficheskii tip vozdeistviia. Biotekhnologicheskii protcess stanovleniia ekologicheskoi ustoichivosti edafotopa. Dnepropetrovsk, 216 p. [In Russian].

29. Pilipko, E. N. (2014). Vliianie roiushhei deiatelnosti kabana Sus scrofa (L.) na fiziko-khimicheskie parametry pochvy elnika kislichnogo. Uchenye zapiski Petrozavodskogo gosudarstvennogo universiteta, 8(1), 34-39. [In Russian].

30. Pogrebniak, P. S. (1955). Osnovy lesnoi tipologii. (2nd ed. add. and revised). Kyiv: Izd-vo Akademii Nauk Ukrainskoi SSR, 456 p. [In Russian].

31. Rozenberg, G. S. (1976). Nekotorye voprosy optimizatcii protcessa raspoznavaniia uslovii sredy po rastitelnosti. Aspekty optimizatcii kolichestvennykh issledovanii rastitelnosti. Ufa, 6-34. [In Russian].
32. Semenov, V. M., \& Kogut, B. M. (2015). Pochvennoe organicheskoe veshhestvo. Moscow: GEOS, 233 p. [In Russian].

33. Shkudor, V. D. (2006). Dynamika roslynnoho riznomanittia pislia sutsilnykh rubok holovnoho korystuvannia u volohykh suborakh Zakhidnoho Polissia. Forestry and Agroforestry, 109, 97-103. [In Ukrainian].

34. Tcyganov, D. N. (1983). Fitoindikatciia ekologicheskikh faktorov v podzone khvoino-shirokolistvennykh lesov. Moscow: Nauka, 198 p. [In Russian].

35. Volokh, A. M., \& Grin, D. S. (2016). Okhotnichi zveri Stepnoi Ukrainy: monografiia. Kherson, 572 p. [In Russian].

36. Vorobev, D. V. (1967). Metodika lesotipologicheskikh issledovanii. Kyiv: Urozhai, 388 p. [In Russian].

37. Zhadobin, A. V., Kazeev, K. Sh., Lesina, A. L., Aleksandrov, A. A., Kazeev, D. K., \& Kolesnikov, S. I. (2019). Otcenka ekologicheskogo sostoianiia pochv Rostovskogo zooparka. Vestnik Permskogo natcionalnogo issledovatelskogo politekhnicheskogo universiteta. Prikladnaia ekologiia. Urbanistika, 1, 131-141. https://doi.org/10.15593/2409-5125/2019.01.09

O. L. Kratiuk', O. O. Orlov ${ }^{2}$

${ }^{I}$ Polissia National University, Zhytomyr, Ukraine ${ }^{2}$ SI "Institute of Environment Geochemistry of NAS of Ukraine", Kyiv, Ukraine

\section{CHANGE OF SOIL PARAMETERS IN FRESH OAK-CONIFEROUS FOREST CONDITIONS UNDER THE INFLUENCE OF SEMI-FREE MAINTENANCE OF GAME ANIMALS IN CENTRAL POLISSYA}

The research was conducted in fresh oak-coniferous forest conditions $\left(\mathrm{V}_{2}-\mathrm{dS}\right)$ on the territory of 2 semi-free maintenance enclosures in hunting farms of Baranivske Hunting Forestry State Enterprise (Yavnenske Forestry) and KSK Club LLC (Potashnyanske Forestry of Radomyshl State Forestry Enterprise) in Central Polissya, based on 24 full geobotanic descriptions, within 4 biogeocenoses. Comparison of scores of soil parameters was performed on undisturbed forest trial plots and disturbed ones under influence of semi-free maintenance of ungulates. The results of research have shown that the mean score of soil humidity was $11.93^{ \pm 0.12}$ on the control plots, and in enclosures $-11.89^{ \pm 0.11}$, difference in reported mean values wasnt essential on $95 \%$ confidence level. Variability of soil humidity on control plots was characterized by the mean score $5.36^{ \pm 0.11}$, increasing in enclosures to $5.94^{ \pm 0.14}$ score $\left(F_{\text {fact. }}=\right.$ $\left.10.58>F_{0.95}=4.30\right)$. The mean score of soil acidity on control plots was $5.80^{ \pm 0.12}$, increasing in enclosures to $6.49^{ \pm 0.11}\left(F_{\text {fact. }}=17.36\right.$ $>F_{0.95}=4.30$ ) which probably was determined by bringing of salts of natrium and potassium to the soil with ungulates urine. The mean score of total salt content in the soil on the control plots equalled $5.33^{ \pm 0.01}$ whereas in enclosures the index increase was fixed up to $5.78^{ \pm 0.12}$ mainly due to bringing of salts to the soil with ungulates excrement. Mentioned above differences of the mean values were essential on $5 \%$ significance level $\left(F_{\text {fact. }}=9.14>F_{0.95}=4.30\right)$. Quantity of calcium and magnesium in the soils of control plots and enclosures was characterized by the mean score $5.56^{ \pm 0.12}$ and $5.97^{ \pm 0.11}$ respectively, an essential increase of their content took place in enclosures $\left(F_{\text {fact }}=6.29>F_{0.95}=4.30\right)$. An increase of content of mineral nitrogen was found in the soils ranging from $4.16^{ \pm 0.01}$ scores on control plots to $4.74^{ \pm 0.11}$ scores in enclosure maintenance of ungulates $\left(F_{\text {fact. }}=27.33>>F_{0.95}=4.30\right)$, which testifies about an essential bringing of nitrous substances to the soil with animals urine. The mean scores of soil aeration were equalled $6.38^{ \pm 0.08}$ and $6.46^{ \pm 0.08}$ respectively; these values didnt differ essentially on $5 \%$ significance level $\left(F_{\text {fact. }}=0.46<<F_{0.95}=4.30\right)$ on the control plots and plots of semi-free maintenance of ungulates. The research conducted can become the basis of further investigation of the influence of semi-free maintenance of game animals on soil parameters in certain forest ecological conditions.

Keywords: phytoindication; forest ecosystems; forest type; enclosure; ungulates. 